\title{
Wolbachia Endosymbiant Was Not Detected in Field Collected Population of Head and Body Lice From Iran Using Molecular Markers
}

\author{
Samira Firooziyan \\ Tehran University of Medical Sciences \\ Ali Sadaghianifar \\ Urmia University of Medical Sciences \\ Fereshteh Gahvehchi Khaligh \\ Urmia University of Medical Sciences \\ Mohammad Ali Oshaghi \\ Tehran University of Medical Sciences
}

Saber Gholizadeh ( $\square$ sabergholizadeh@yahoo.com )

Urmia University of Medical Sciences https://orcid.org/0000-0002-3255-8098

\section{Research note}

Keywords: Pediculus, Endosymbiant, Molecular Detection, Iran

Posted Date: October 6th, 2020

DOI: https://doi.org/10.21203/rs.3.rs-78236/v1

License: (c) (1) This work is licensed under a Creative Commons Attribution 4.0 International License. Read Full License 


\section{Abstract}

Objectives

Head lice infection can lead to inferiority, depression, insomnia, and lack of education, loss of social status, secondary infections, hair removal, and allergies. Body lice can carry dangerous diseases such as typhus, trench fever, and recurrent fever. Studies on lice control due to pesticides, inappropriate drug use, pesticide risks, and pesticide resistance in the lice population are needed. The study of insect symbiotic microorganisms such as Wolbachia is a new approach to control the vector-borne disease.

Results

The presence of this bacterium was investigated in head and body lice collected from the Iranian lice population. Genomic DNA was extracted from both lice specimens and PCR assay was performed to the detection of Wolbachia infection by using Wsp, coxA, and gatB primers. All PCR results were negative for Wolbachia in comparison with positive controls. Further studies should be performed using new molecular markers to determine the Wolbachia infection of lice.

\section{Introduction}

Head lice (Pediculus capitis) live on human hair and may be responsible for pruritus that may lead to high irritation and even wound infection [1]. They are transmitted through proximity with infested persons, or the sharing of combs and hair products [2]. Body lice (Pediculus humanus) live in clothes and may be responsible for the transmission of epidemic typhus, relapsing, and trench fever. Body lice are transmitted through shared clothing or physical contact with infested persons. Pubic lice (Pthirus pubis) are not investigated here, and sections relating to them should be removed [1].

lice are a global problem, whose prevalence remains high due to ineffective control strategies and resistance to common chemical treatments [3]. Resistance to anti-lice so far from several countries including the United States, United Kingdom, Argentina, Australia, Israel, France, and Iran has been reported [3-8]. Due to the sensitivity of the subject, the high prevalence of lice infestation in different parts of the world, spending a lot of money and energy to treat the infection, which has different effects, the study of insect symbiont microorganisms is a new approach in the world [9].

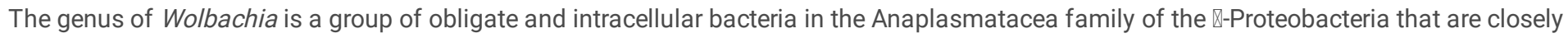
related to the Rickettsia species [10]. It is one of the most common parasiticmicrobes and is possibly the most common reproductive parasite in the biosphere [11]. Interactions of Wolbachia with its hosts are often complex, and in some cases have evolved to be mutualistic rather than parasitic [12]. Some host species cannot reproduce, or even survive, without Wolbachia colonization [13]. It was estimated infection at least 40$66 \%$ of arthropod species are infected with Wolbachia $[2,14-18]$. Wolbachia is present in the reproductive tissues, testis, and ovaries, of a wide range of arthropods, and transmitted through the egg cytoplasm to the next generation [19]. It causes cytoplasmic incompatibility between strains and species, parthenogenesis induction, feminization, male-killing, and enhanced fecundity and fertility in their hosts [20]. It is suspected that Wolbachia would play a decisive role in causing reproductive manipulations by interacting with the host proteins [21].

The genus Wolbachia is genetically very diverse based on the sequencing of ftsz and 16S rDNA genes. While eight "subgroups" (A-H) have been identified to date [22-26], only subgroup F has been reported in lice [27]. The Wolbachia surface protein (wsp) is often used for detection and phylogenetic analysis of Wolbachia [28]. The wsp is an eight beta-barrel transmembrane protein that participates in host immune response, cell proliferation, pathogenicity, and controlled cell death program [29]. Wolbachia has been detected in the lice populations from Australia, Canada, USA, and Argentina using the wsp marker [27].

In the current study, Wolbachia has not been detected in lice samples, this could be due to mutations in the Wsp priming sites, hence additional primers should be tried before concluding that Wolbachia is absent. Interestingly, lice samples collected from the USA, Madagascar, and Russia was not infected with Wolbachia using the same marker [30].

\section{Methods}

Overall 123 human head and body lice samples were collected in West Azerbaijan, Khorasan, Qom, and Zanjan from the head and body of volunteers (Figure 1 and Table 1). Head lice samples ( $n=97)$ were collected from the screening of 24 school student people who are seeking treatment in health centers and trained health workers. Body lice samples $(n=26)$ were collected from 21 persons living in addiction treatment camps by collecting clothes and exchanging them with new clothes. Written informed consent (in Persian) was obtained from interested individuals, volunteers, and the parents or legal guardians of the children. 
Head lice $(n=49)$ and body lice $(n=26)$ specimens were randomly subjected to genomic DNA extraction. Genomic DNA was extracted from the whole body of each louse stored in 70\% ethanol using the YTA Genomic DNA Extraction Mini Kit (Yekta Tajhiz Azma, Tehran, Iran). The DNA extraction process was followed based on the manufacturer's instructions with slight modification. Briefly, each louse was frizzed and towed in liquid nitrogen, then homogenized in the $200-\mu$ FATG1 buffer (cell lysis) using a micropestle. After the addition of $20-\mu l$ proteinase $\mathrm{K}$, the mixture was incubated at $60^{\circ} \mathrm{C}$ for $1 \mathrm{~h}$. The rest of the DNA extraction process was followed based on the YTA protocol.

A nested-PCR assay was performed to the detection of Wolbachia infection of the lice by using the wsp marker [28]. Initially, 81F and 691R primers were used to amplify 632 bp of the partial sequence of the Wsp gene. The PCR product of the first step was applied as a template for the second step using $183 \mathrm{~F}$ and 691R primers to amplify a $501 \mathrm{bp}$ fragment [28]. Wolbachia infection of samples was checked again by using cytochrome oxidase subunit 1 ( $\operatorname{cox} A)$ and Glutamyl-Trna (G/n) amidotransferase, subunit B (gatB) primers [31]. They could amplify 650 bp and 500 bp fragments, respectively [31].

PCR reactions $(25 \mu \mathrm{l})$ were performed in thin-walled microcentrifuge tubes. The optimized reaction condition was $1 \mu$ l of genomic DNA, $1 \mu$ l both forward and reverse primers, $12.5 \mu$ l Master Mix (Yekta Tajhiz Azma, Tehran, Iran), and $7.5 \mu l$ ddH2O. The details of the amplification profile for each pair of primers have been presented in Table 2. The positive control was used DNA from Wolbachia positive Culex mosquitoes and $1 \mu$ l of distilled deionized water was used as the negative control. The DNA for positive test samples were extracted at the same time and place.

PCR products were visualized on a 1.5\% agarose gel containing safe stain (Yekta Tajhiz Azma, Tehran, Iran) and using a UV transilluminator.

\section{Results}

Overall 75 lice specimens ( $n=49$ head lice and $n=26$ body lice) from four different provinces of Iran were tested for Wolbachia infection. All nested-PCR and PCR results were negative for Wolbachia in comparison with a positive control to $\operatorname{coxA}$, gatB, and wsp gene. Wolbachia was not detected in all specimens using all 3 primers.

\section{Discussion}

In the class of insects, Wolbachia has been identified from some orders, in some others has not been detected and in some others has not been studied [32].

Different studies in Iran show variation in Wolbachia infection rates across wild-caught mosquito species, Pederus beetles, fruit fly species, sandfly species [33-36]. Also, there were different unpublished sequences of Wolbachia in GenBank submitted by Djadid et al., from Culex pipiens species (GenBank IDs: EF539841-52 and DQ900650-54) during 2006-2007. The current study is the first report on the Wolbachia investigation in human head and body lice in Iran.

Recently, different studies were undertaken on endosymbionts detection in louse in different geographical regions [37-40]. However, not all of them have succeeded in isolating the bacteria. Veracx et al. (2005) have not been detected with wsp the Wolbachia bacteria from body lice but have been isolated from head lice [41]. Also, it was not detected using Wsp primers in head lice collected from the USA, Russia, and Madagascar [30]. In the current study, Wolbachia infection was not detected in head and body lice samples, despite using three different molecular markers, $w s p, \operatorname{cox} A$, and gatB. Since the positive control worked properly, it does not seem to be a technical problem such as incorrect test technique, a problem in connecting primers, problems in the raw material used, and so on.

\section{Conclusion}

The failure to detect Wolbachia in the previous studies has been expressed due to the inability of insects to support the physiology of Wolbachia, changes in tropical Wolbachia tissue, and inhibition of native microbiome [42-44]. It is not correct to ignore the non-diagnosis of Wolbachia in the population of lice due to their resistance to chemical insecticides. However, further investigations with more sample collection from different parts of the country using ftsz, 16 sRNA, and end-point PCR targeting ARM (A supergroup repeat motif) [45] markers, also, Next Generation Sequencing may provide better sensitivity and efficiency of Wolbachia detection even in low titer Wolbachia infections.

\section{Limitations}

- Sample collection restricted from limited to four provinces of the country because of funding limitations.

- Limited molecular markers were used due to student project and limited funding.

\section{Abbreviations}

wsp (Wolbachia surface protein) 
YTA (Yekta Tajhiz Azma)

$\operatorname{coxA}$ (cytochrome oxidase subunit 1)

gatB (Glutamyl-Trna amidotransferase, subunit B)

ARM (A supergroup repeat motif)

\section{Declarations}

\section{Acknowledgment}

The authors express their gratitude to the Cellular and Molecular Research Center, Urmia University of Medical Sciences, Urmia, Iran for technical support.

\section{Authors' contributions}

Conceived and designed the study: SG and SF. Search and data selection: SG, AS, FGK and SF. analyzed the data: SG, SF, and ML. Wrote the paper: SF, SG, FGK, and MAO. All authors read and approved the final manuscript.

\section{Funding}

This work financially supported by the National Institute for Medical Research Development Grant No. 957921.

\section{Availability of data and materials}

Data supporting this article are included within the article and supplementary file.

\section{Ethics approval and consent to participate}

Written informed consent (in Persian) was obtained from interested individuals, volunteers, and the parents or legal guardians of the children. The study was approved in ethics committee in National Institute for Medical Research Development (NIMAD) with ID number

IR.NIMAD.REC.1396.108.

\section{Consent for publication}

Not applicable

\section{Competing interests}

The authors declare that they have no competing interests.

\section{Author details}

${ }^{1}$ Cellular and Molecular Research Center, Cellular and Molecular Medicine Institute, Urmia University of Medical Sciences, Urmia, Iran.

${ }^{2}$ Medical Entomology Department, School of Public Health, Urmia University of Medical Sciences, Urmia, Iran.

*Corresponding Author: sabergholizadeh@yahoo.com, saber@umsu.ac.ir

\section{References}

1. Badiaga S, Brouqui P: Human louse-transmitted infectious diseases. Clinical microbiology and infection 2012, $18(4): 332-337$.

2. Firooziyan S, Sadaghianifar A, Taghilou B, Galavani H, Ghaffari E, Gholizadeh S: Identification of novel voltage-gated sodium channel mutations in human head and body lice (Phthiraptera: Pediculidae). Journal of medical entomology 2017, 54(5):1337-1343.

3. Mumcuoglu KY: Prevention and treatment of head lice in children. Pediatric Drugs 1999, 1(3):211-218.

4. Clark JM: Determination, mechanism and monitoring of knockdown resistance in permethrin-resistant human head lice, Pediculus humanus capitis. Journal of Asia-Pacific Entomology 2009, 12(1):1-7.

5. Burkhart CG, Burkhart CN: Head lice therapies revisited. Dermatology online journal 2006, 12(6):3.

6. Burgess IF, Burgess NA: Dimeticone 4\% liquid gel found to kill all lice and eggs with a single 15 minute application. BMC research notes 2011, 4(1):15. 
7. Kurt Ö, Balcıoğlu IC, Burgess IF, Limoncu ME, Girginkardeşler N, Tabak T, Muslu H, Ermiş Ö, Sahin MT, Bilac C: Treatment of head lice with dimeticone 4\% lotion: comparison of two formulations in a randomised controlled trial in rural Turkey. BMC Public Health 2009, 9 (1):441.

8. Kamalinejad M, Sharif A, Gachkar L, Ehsani AH, Ahmadian-Attar M, Torabi MR: Investigating the Efficacy of Sumac Topical Solution Against Permethrin-resistant Human Head Lice. International Journal of Medical Toxicology and Forensic Medicine 2019, 9(3 (Summer)):117-124.

9. Sazama EJ, Ouellette SP, Wesner JS: Bacterial endosymbionts are common among, but not necessarily within, insect species. Environmental entomology 2019, 48(1):127-133.

10. O'Neill SL, Giordano R, Colbert A, Karr TL, Robertson HM: 16S rRNA phylogenetic analysis of the bacterial endosymbionts associated with cytoplasmic incompatibility in insects. Proceedings of the National Academy of Sciences 1992, 89(7):2699-2702.

11. Rousset F, Bouchon D, Pintureau B, Juchault $P$, Solignac M: Wolbachia endosymbionts responsible for various alterations of sexuality in arthropods. Proceedings of the Royal Society of London Series B: Biological Sciences 1992, 250(1328):91-98.

12. Stouthamer R, Breeuwer J, Luck R, Werren J: Molecular identification of microorganisms associated with parthenogenesis. Nature 1993, 361(6407):66-68.

13. Simsek S, Ciftci AT: Serological and molecular detection of Dirofilaria species in stray dogs and investigation of Wolbachia DNA by PCR in Turkey. Journal of arthropod-borne diseases 2016, 10(4):445.

14. Sazama EJ, Bosch MJ, Shouldis CS, Ouellette SP, Wesner JS: Incidence of Wolbachia in aquatic insects. Ecology and evolution 2017, 7(4):1165-1169.

15. Werren JH, Windsor D, Guo LR: Distribution of Wolbachia among neotropical arthropods. Proceedings of the Royal Society of London Series B: Biological Sciences 1995, 262(1364):197-204.

16. Kozek WJ, Rao RU: The discovery of Wolbachia in arthropods and nematodes-A historical perspective. In: Wolbachia: a bug's life in another bug. vol. 5: Karger Publishers; 2007: 1-14.

17. Werren JH, Windsor DM: Wolbachia infection frequencies in insects: evidence of a global equilibrium? Proceedings of the Royal Society of London Series B: Biological Sciences 2000, 267(1450):1277-1285.

18. Kittayapong P, Jamnongluk W, Thipaksorn A, Milne J, Sindhusake C: Wolbachia infection complexity among insects in the tropical rice-field community. Molecular Ecology 2003, 12(4):1049-1060.

19. Werren JH, Zhang W, Guo LR: Evolution and phylogeny of Wolbachia: reproductive parasites of arthropods. Proceedings of the Royal Society of London Series B: Biological Sciences 1995, 261(1360):55-63.

20. Bensaadi-Merchermek N, Salvado J-C, Cagnon C, Karama S, Mouchès C: Characterization of the unlinked 16S rDNA and 23S-5S rRNA operon of Wolbachia pipientis, a prokaryotic parasite of insect gonads. Gene 1995, 165(1):81-86.

21. Kirkness EF, Haas BJ, Sun W, Braig HR, Perotti MA, Clark JM, Lee SH, Robertson HM, Kennedy RC, Elhaik E: Genome sequences of the human body louse and its primary endosymbiont provide insights into the permanent parasitic lifestyle. Proceedings of the National Academy of Sciences 2010, 107(27):12168-12173.

22. Werren JH: Wolbachia and speciation. Endless forms: species and speciation 1998:245-260.

23. Lo N, Casiraghi M, Salati E, Bazzocchi C, Bandi C: How many Wolbachia supergroups exist? Molecular biology and evolution 2002, 19(3):341-346.

24. Bordenstein S, Rosengaus RB: Discovery of a novel Wolbachia supergroup in Isoptera. Current microbiology 2005, 51(6):393-398.

25. Lo N, Paraskevopoulos C, Bourtzis K, O'Neill SL, Werren J, Bordenstein S, Bandi C: Taxonomic status of the intracellular bacterium Wolbachia pipientis. International journal of systematic and evolutionary microbiology 2007, 57(3):654-657.

26. Ros VI, Fleming VM, Feil EJ, Breeuwer JA: How diverse is the genus Wolbachia? Multiple-gene sequencing reveals a putatively new Wolbachia supergroup recovered from spider mites (Acari: Tetranychidae). Appl Environ Microbio/ 2009, 75(4):1036-1043.

27. Covacin C, Barker SC: Supergroup F Wolbachia bacteria parasitise lice (Insecta: Phthiraptera). Parasitology research 2007, 100(3):479.

28. Zhou W, Rousset F, O'Neill S: Phylogeny and PCR-based classification of Wolbachia strains using wsp gene sequences. Proceedings of the Royal Society of London Series B: Biological Sciences 1998, 265(1395):509-515.

29. Baldo L, Desjardins CA, Russell JA, Stahlhut JK, Werren JH: Accelerated microevolution in an outer membrane protein (OMP) of the intracellular bacteria Wolbachia. BMC evolutionary biology 2010, 10(1):48.

30. Anderson M: Detection of Wolbachia in Human Lice. 2016.

31. Baldo L, Dunning Hotopp JC, Jolley KA, Bordenstein SR, Biber SA, Choudhury RR, Hayashi C, Maiden MC, Tettelin H, Werren JH: Multilocus sequence typing system for the endosymbiont Wolbachia pipientis. Appl Environ Microbiol 2006, 72(11):7098-7110.

32. Werren JH: Biology of wolbachia. Annual review of entomology 1997, 42(1):587-609.

33. Bozorg-Omid F, Oshaghi MA, Vahedi M, Karimian F, Seyyed-Zadeh SJ, Chavshin AR: Wolbachia infection in West Nile Virus vectors of northwest Iran. Applied Entomology and Zoology 2020, 55(1):105-113. 
34. Maleki-Ravasan N, Akhavan N, Raz A, Jafari M, Zakeri S, Dinparast Djadid N: Co-occurrence of pederin-producing and Wolbachia endobacteria in Paederus fuscipes Curtis, 1840 (Coleoptera: Staphilinidae) and its evolutionary consequences. MicrobiologyOpen 2019, 8(7):e00777.

35. Karimi J, Darsouei R: Presence of the endosymbiont Wolbachia among some fruit flies (Diptera: Tephritidae) from Iran: A multilocus sequence typing approach. Journal of Asia-Pacific Entomology 2014, 17(1):105-112.

36. Bordbar A, Soleimani S, Fardid F, Zolfaghari M, Parvizi P: Three strains of Wolbachia pipientis and high rates of infection in Iranian sandfly species. Bulletin of entomological research 2014, 104(2):195-202.

37. Allen JM, Reed DL, Perotti MA, Braig HR: Evolutionary relationships of "Candidatus Riesia spp.," endosymbiotic Enterobacteriaceae living within hematophagous primate lice. Applied and Environmental Microbiology 2007, 73(5):1659-1664.

38. Sasaki-Fukatsu K, Koga R, Nikoh N, Yoshizawa K, Kasai S, Mihara M, Kobayashi M, Tomita T, Fukatsu T: Symbiotic bacteria associated with stomach discs of human lice. Applied and environmental microbiology 2006, 72(11):7349-7352.

39. Perotti MA, Kirkness EF, Reed DL, Braig HR: Endosymbionts of lice. Insect symbiosis 2008, 3:205-219.

40. Kyei-Poku G, Colwell D, Coghlin P, Benkel B, Floate K: On the ubiquity and phylogeny of Wolbachia in lice. Molecular Ecology 2005, 14(1):285-294.

41. Veracx A, Raoult D: Biology and genetics of human head and body lice. Trends in parasitology 2012, 28(12):563-571.

42. Kittayapong P, Baisley KJ, Baimai V, O’Neill SL: Distribution and diversity of Wolbachia infections in Southeast Asian mosquitoes (Diptera: Culicidae). Journal of medical entomology 2000, 37(3):340-345.

43. Osei-Poku J, Han C, Mbogo CM, Jiggins FM: Identification of Wolbachia strains in mosquito disease vectors. PLoS One 2012, 7(11):e49922.

44. Johnson KN: The impact of Wolbachia on virus infection in mosquitoes. Viruses 2015, 7(11):5705-5717.

45. Schneider DI, Klasson L, Lind AE, Miller WJ: More than fishing in the dark: PCR of a dispersed sequence produces simple but ultrasensitive Wolbachia detection. BMC microbiology 2014, 14(1):121.

\section{Tables}

Table 1. Number of lice collected and location of Iranian cities where lice were collected

\begin{tabular}{|lllll|}
\hline Provine & District & Latitude and Longitude & Number of head and body Lice & Date of collection \\
\hline Khorasan-Razavi & Mashhad & $36.26^{\circ} \mathrm{N}$ and $59.62^{\circ} \mathrm{E}$ & 21 & 2018 \\
\hline Qom & Qom & $34.64^{\circ} \mathrm{N}$ and $50.87^{\circ} \mathrm{E}$ & 15 & 2018 \\
\hline Zanjan & Zanjan & $36.68^{\circ} \mathrm{N}$ and $48.51^{\circ} \mathrm{E}$ & 9 & 2017 \\
\hline West Azerbaijan & Salmas & $38.20^{\circ} \mathrm{N}$ and $44.77^{\circ} \mathrm{E}$ & 19 & 2017 \\
\cline { 2 - 5 } & Urmia & $37.55^{\circ} \mathrm{N}$ and $45.08^{\circ} \mathrm{E}$ & 59 & $2017-2019$ \\
\hline
\end{tabular}

Table 2. Nested-PCR and PCR amplification conditions. Steps two to four were repeated 36 times.

\begin{tabular}{|c|c|c|c|c|c|c|c|c|c|c|c|}
\hline \multirow{2}{*}{$\begin{array}{l}\text { Nested- } \\
\text { PCR/ } \\
\text { PCR }\end{array}$} & \multirow[t]{2}{*}{ Primer } & \multicolumn{2}{|c|}{ Initial denaturation } & \multicolumn{2}{|l|}{ Denaturation } & \multicolumn{2}{|l|}{ Annealing } & \multicolumn{2}{|l|}{ Extension } & \multicolumn{2}{|c|}{ Final Extension } \\
\hline & & Temperature & Time & Temperature & Time & Temperature & Time & Temperature & Time & Temperature & Time \\
\hline $\begin{array}{l}\text { Nested- } \\
\text { PCR }\end{array}$ & $w s p$ & $95 \circ \mathrm{C}$ & $\begin{array}{l}5 \\
\min \end{array}$ & $95 \circ \mathrm{C}$ & $1 \mathrm{~min}$ & $55 \circ \mathrm{C}$ & $\begin{array}{l}90 \\
\text { sec }\end{array}$ & $72 \circ \mathrm{C}$ & $\begin{array}{l}80 \\
\text { sec }\end{array}$ & $72 \circ \mathrm{C}$ & $\begin{array}{l}10 \\
\min \end{array}$ \\
\hline PCR & $\operatorname{cox} A$ & $94 \circ \mathrm{C}$ & $\begin{array}{l}5 \\
\min \end{array}$ & $94 \circ \mathrm{C}$ & $\begin{array}{l}15 \\
\text { sec }\end{array}$ & $55^{\circ} \mathrm{C}$ & $\begin{array}{l}15 \\
\text { sec }\end{array}$ & $72 \circ \mathrm{C}$ & $\begin{array}{l}30 \\
\text { sec }\end{array}$ & $72 \circ \mathrm{C}$ & $\begin{array}{l}10 \\
\min \end{array}$ \\
\hline PCR & gatB & $94 \circ \mathrm{C}$ & $\begin{array}{l}2 \\
\min \end{array}$ & $94 \circ \mathrm{C}$ & $\begin{array}{l}30 \\
\text { sec }\end{array}$ & $56 \circ \mathrm{C}$ & $\begin{array}{l}45 \\
\text { sec }\end{array}$ & $72 \circ \mathrm{C}$ & $\begin{array}{l}1.30 \\
\min \end{array}$ & $70 \circ \mathrm{C}$ & $\begin{array}{l}10 \\
\min \end{array}$ \\
\hline
\end{tabular}

\section{Figures}




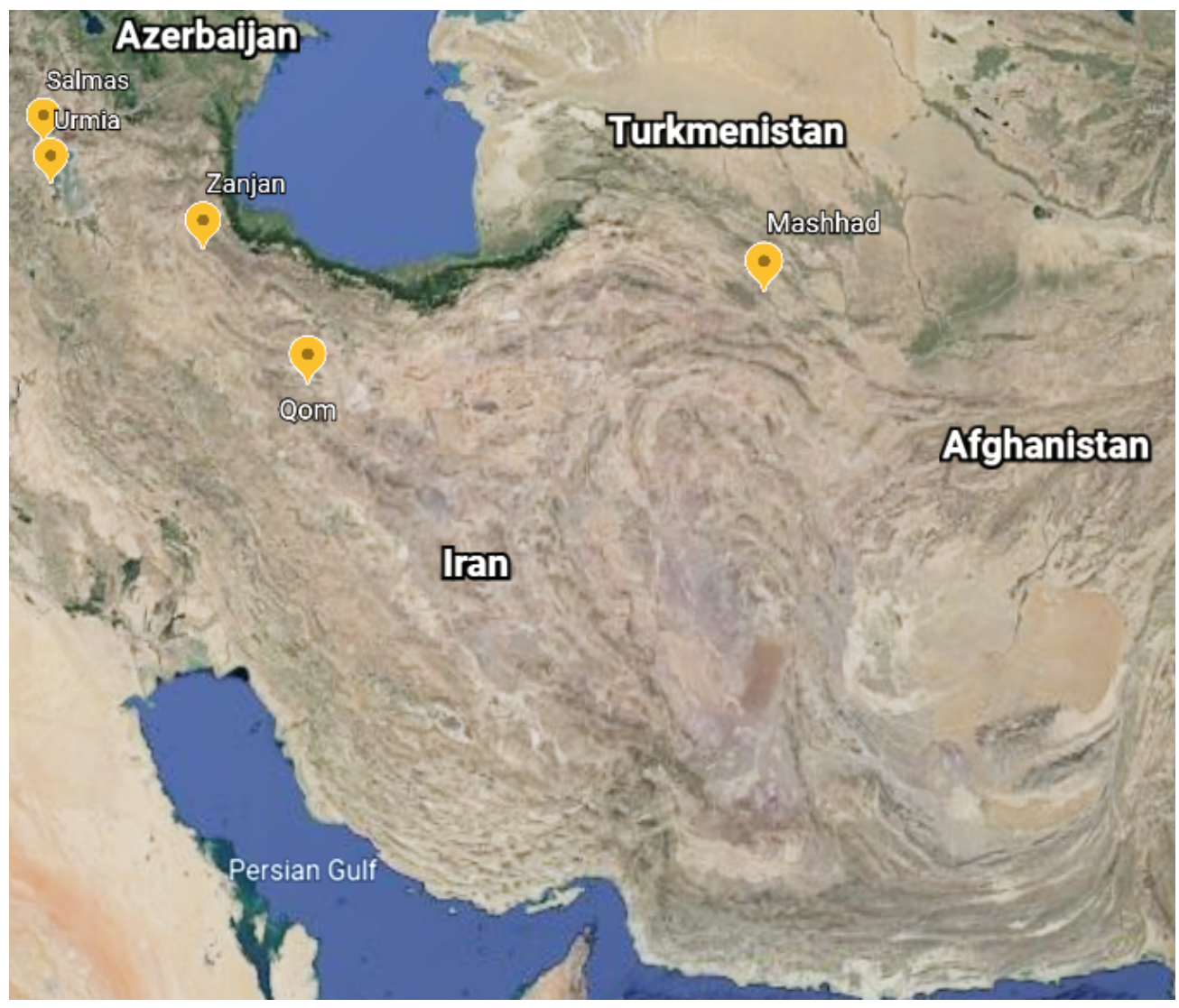

Figure 1

Locations of lice specimens' collection in Iran (Google. 2020. Google maps sample collection locations in Iran. Retrieved July 27, 2020, from https://www.google.com/maps/place/Iran). 